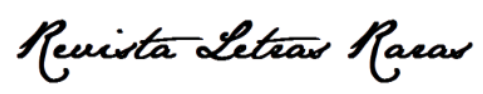

ISSN: 2317-2347 - v. 9 , n. 2 (2020)

Todo o conteúdo da RLR está licenciado sob Creative Commons Atribuição 4.0 Internacional

\title{
Literatura e representação: uma análise crítica de Cacau, de
}

\author{
Jorge Amado / \\ Literature and representation: a critical analysis of 'Cacau', by
}

\author{
Jorge Amado
}

José Otávio Monteiro Badaró Santos *

Graduado em Comunicação Social - Jornalismo, com Especialização em Literatura Brasileira, Formação do Cânone e Contrapontos Críticos - Universidade do Estado da Bahia (UNEB) e cursando Mestrado em Memória: Linguagem e Sociedade (PPGMLS) na Universidade Estadual do Sudoeste da Bahia (UESB).

(iD) https://orcid.org/0000-0002-9756-5985

Oton Magno Santana dos Santos*

Graduado em Letras com habilitação em Inglês, pela Universidade Estadual de Santa Cruz (2000), Especialista em Estudos Comparados em Literaturas de Língua Portuguesa (2004), Mestre em Letras: Linguagens e Representações (UESC) (2010) e Doutor em Educação pela UNICAMP (2017).

(iD) https://orcid.org/0000-0002-6872-4799

\section{Mateus Santos Souza ${ }^{* * * t}$}

Mestre em Educação, pelo Programa de Pós-Graduação em Educação e Contemporaneidade (PPGEduC) pela Universidade do Estado da Bahia; Especialista em Política e Relações Internacionais pela FESPSP (2016); Bacharel em Comércio Exterior pela Universidade Ibirapuera (2007).

iD https://orcid.org/0000-0001-5174-9407

Recebido: 14 abr. 2020. Aprovado: 01 mai. 2020

\section{Como citar este artigo:}

BADARÓ SANTOS, José Otávio; SANTOS, Oton Magno Santana dos; SOUZA, Mateus Santos. Literatura e representação: uma análise crítica de Cacau, de Jorge Amado. Revista Letras Raras. Campina Grande, v. 9, p. 51-67 n. 2, maio 2020.

\footnotetext{
* $\$ juca_badaro@hotmail.com

** $\triangle$ otonmagno@gmail.com

*** teutato1@gmail.com
} 


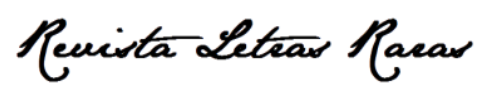

ISSN: 2317-2347 - v. 9 , n. 2 (2020)

Todo o conteúdo da RLR está licenciado sob Creative Commons Atribuição 4.0 Internacional

RESUMO

O presente texto pretende analisar o romance Cacau (1933), de Jorge Amado, em uma perspectiva da literatura como representação, na esteira dos estudos de Louis Marin e Roger Chartier, considerando o texto literário como a representação das sensibilidades de determinados homens, em determinadas épocas, da ideia que faziam de sua própria sociedade, dos significados que almejavam construir, ou a maneira como apreendiam o mundo em que viviam. Nesse sentido, propomos uma oposição à ideia de que a referida obra, circunscrita pela crítica marxista como romance proletário e regionalista, é uma homologia das estruturas sociais da realidade que lhe é referente, uma vez que buscamos construir um estudo mais próximo das correntes teóricas que investigam a cultura não como um nível de realidade adstrito às determinações socioeconômicas, mas como uma dimensão complexa do homem que, de maneira alguma, pode ser explicada por modelos reducionistas e deterministas. Assim, a noção de representação nos permitiu compreender as relações que 0 autor ou o grupo do qual ele fez parte mantiveram com o mundo social, como uma construção multifacetada, constituída de posições, escolhas e interesses. Baseado em Jauss, propomos que não há um sentido oculto, mas uma significação que se dá na relação obra e leitor.

PALAVRAS-CHAVE: Representação; Romance; Jorge Amado; Cacau

\section{ABSTRACT}

This text intends to analyze the novel Cacau (1933), by Jorge Amado, in a perspective of literature as representation, in the wake of the studies of Louis Marin and Roger Chartier, considering the literary text as the representation of the sensibilities of certain men, in certain times, the idea they made of their own society, the meanings they wanted to build, or the way they understood the world in which they lived. In this sense, we propose an opposition to the idea that the referred work, circumscribed by Marxist criticism as a proletarian and regionalist novel, is a homology of the social structures of reality that refer to it, since we seek to build a study closer to the theoretical currents that they investigate culture not as a level of reality attached to socioeconomic determinations, but as a complex dimension of man that, in no way, can be explained by reductionist and deterministic models. Thus, the notion of representation allowed us to understand the relationships that the author or the group of which he was part had with the social world, as a multifaceted construction, constituted of positions, choices and interests. Based on Jauss, we propose that there is no hidden meaning, but a meaning that occurs in the relationship between work and reader.

KEYWORDS: Representation; Romance; Jorge Amado; Cocoa

\section{Introdução}

Em 1933, Jorge Amado publicou seu segundo romance, Cacau, dando início àquilo que a crítica literária brasileira denominou de o "ciclo do cacau" da literatura amadiana, constituído de narrativas ambientadas na região sul da Bahia e que, de maneira geral, trataram de representar as relações sociais no seio do coronelismo cacaueiro, marcadas profundamente pela desigualdade e pelo poder repressivo das grandes oligarquias rurais. É assim com Terras do Sem Fim (1943), que narra a conquista da terra pelos primeiros desbravadores da região e a disputa entre duas famílias rivais; São Jorge dos Ilhéus (1944), que aborda a derrocada dos coronéis e a ascensão do capital estrangeiro na exploração do cacau; bem como com Gabriela, cravo e canela (1958), que trata a sociedade cacaueira sob a perspectiva da crônica de costumes; e, por fim, a mesma temática sendo retomada mais de 50 anos depois com Tocaia 


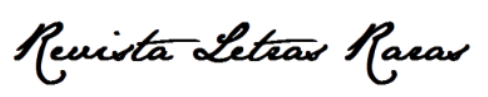

ISSN: 2317-2347 - v. 9 , n. 2 (2020)

Todo o conteúdo da RLR está licenciado sob Creative Commons Atribuição 4.0 Internacional

grande (1984), que propõe, em um ímpeto de reparação, refazer a genealogia das cidades grapiúnas a partir do ponto de vista dos vencidos e não mais dos vencedores.

Conforme Aguiar (2018), Cacau teve uma tiragem inicial de dois mil exemplares que se esgotaram em pouco mais de um mês, tornando o autor estreante um sucesso de público, porém por uma razão menos literária do que política: "os palavrões contidos na obra fizeram com que a edição fosse recolhida das livrarias" (AGUIAR, 2018, p.69). O escritor e os editores do livro precisaram recorrer a amigos, influentes no governo Vargas, que intercederam e conseguiram a liberação do livro, causando a sensação de que a própria censura teria contribuído para que o romance fosse um sucesso comercial. Pouco tempo depois, uma segunda edição foi lançada e mais três mil exemplares foram impressos e colocados à venda.

No entanto, além do episódio da censura e da boa aceitação popular, uma pequena nota, na abertura do romance, chamou a atenção de leitores e críticos: "Tentei contar neste livro, com um mínimo de literatura para um máximo de honestidade, a vida dos trabalhadores das fazendas de cacau do sul da Bahia. Será um romance proletário?" (AMADO, 1971, p.121). 0 texto parecia confirmar uma tendência para o engajamento político e ideológico que marcaria uma geração de artistas daquele período. Segundo Candido (2011), a partir de 1930 houve uma grande mobilização no âmbito da cultura e das artes no Brasil, motivada, principalmente, pelo desejo de unificar o país em uma identidade essencialmente brasileira, na esteira do movimento modernista deflagrado em 1922. Havia um interesse muito grande nesse sentido, em diversas esferas da cultura, seja no ensino público, na vida artística e literária, nos estudos históricos e sociais e até nos meios de comunicação: o desejo de uma nova tomada de consciência ideológica que exigia uma agudização no engajamento político por parte de artistas e intelectuais. Enquanto uma parte deles era influenciada pela experiência da Revolução de 1917, na Rússia, e a consolidação dos movimentos comunistas pelo mundo, outra estava entusiasmada com a ideologia ultranacionalista, defendida, principalmente, pelo regime de Mussolini, na Itália (CANDIDO, 2011, p.187-188).

O maior empenho dos escritores para que a literatura participasse do debate sobre as questões sociais e os graves problemas que afetavam o Brasil naquele período produziu narrativas que procuravam retratar a realidade dos esquecidos, dos menos favorecidos, dos historicamente espoliados, bem como a decadência das antigas oligarquias nos rincões da nação: 


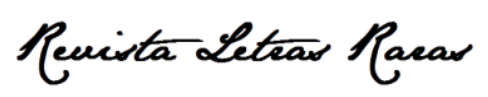

ISSN: 2317-2347 - v. 9 , n. 2 (2020)

Todo o conteúdo da RLR está licenciado sob Creative Commons Atribuição 4.0 Internacional

Romance fortemente marcado de Neo-naturalismo e de inspiração popular, visando os dramas contidos em aspectos característicos do país: decadência da aristocracia rural e formação do proletariado (José Lins do Rego); poesia e luta do trabalhador (Jorge Amado, Amando Fontes); êxodo rural, cangaço (José Américo de Almeida, Raquel de Queirós, Graciliano Ramos); vida difícil das cidades em rápida transformação (Érico Veríssimo) (CANDIDO, 2006, p.130).

Ainda conforme Candido, a crítica brasileira dos anos 40, no entanto, ia no sentido contrário, ao postular que, sob a justificativa do "realismo social", deste modo documental de fazer literatura, muitos autores estariam disfarçando suas próprias deficiências enquanto artistas da palavra, desencadeando um certo desdém pelo formalismo e pela construção estética do texto. Nesse sentido, a nota prévia de Cacau, "um mínimo de literatura para um máximo de honestidade", parecia corroborar esse posicionamento do autor, dando a impressão de que a "honestidade" é pouco compatível com a literatura, uma vez que esta, sinônimo de elaboração formal, prejudicaria a representação fiel da realidade. Alguns críticos reagiram ferozmente a essa modalidade do fazer literário, que ficou conhecida como "romance proletário", e podemos dizer que Wilson Martins, em um texto publicado em 1947 no suplemento literário Arte Literatura, do jornal Folha do Norte, de Belém, no Pará, inaugura o que Eduardo de Assis Duarte chamou de a "crítica dos defeitos" da literatura amadiana (DUARTE, 1996, p.32). Martins, ao discorrer sobre o que considerava uma crise no romance brasileiro naquele período, elencou Jorge Amado como um dos exemplos mais significativos da falta de apuro formal sob a justificativa de representação rigorosa da realidade:

0 caso de um Jorge Amado, oferecendo-nos continuamente o espetáculo de sua decadência literária, seja por se ter em definitivo deixado empolgar pela política partidária, seja (o que reputo mais provável) por ser rapidamente esgotado as suas reservas de originalidade criadora, me parece ser dos mais expressivos (MARTINS, 1947, p.1).

O mesmo juízo de valor sobre os primeiros romances de Amado teve o historiador e crítico literário Sérgio Buarque de Holanda. Em um texto intitulado "Três romances", publicado no mesmo periódico, no ano seguinte, Holanda sugeriu que a preocupação política e as necessidades partidárias impossibilitaram que Amado se desenvolvesse como romancista. Para o historiador, ao contrário de Graciliano Ramos e Raquel de Queiroz, o escritor baiano não soube dar ao seu texto um caráter universal, nem conseguiu alcançar um aprofundamento psicológico em suas personagens, porque "seduzindo à maneira de uma reportagem feliz" seus 


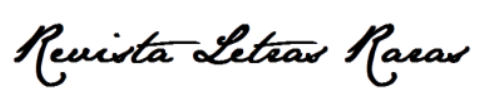

ISSN: 2317-2347 - v. 9 , n. 2 (2020)

Todo o conteúdo da RLR está licenciado sob Creative Commons Atribuição 4.0 Internacional

romances, "embora excitantes para a imaginação", careciam das "qualidades severas e exigentes que se apuram num tirocínio atento e muitas vezes penoso" (HOLANDA, 1948, p.1).

A "crítica dos defeitos", identificada por Duarte, no entanto, encontra em Álvaro Lins o seu maior representante. Crítico literário respeitado, Lins, que em 1955 foi eleito para a Academia Brasileira de Letras, escreveu, ao longo dos anos 40, alguns artigos em que avalia os romances de Jorge Amado publicados até aquele momento. Os textos de Lins influenciaram significativamente toda uma geração de críticos que, nas décadas seguintes, escreveriam antologias e compêndios literários, a exemplo de Alfredo Bosi. Os artigos de Álvaro Lins foram reunidos em Os Mortos de Sobrecasaca: ensaios e estudos 1940-1960, publicado em 1963. Entre as críticas em tom mordaz, Lins afirma que Jorge Amado é um "romancista incompleto e mutilado, em cujas mãos os assuntos e os problemas permanecem em estado natural como a pedir os necessários desenvolvimentos"; assevera ainda que o "principal problema do Sr. Jorge Amado é o da sua ignorância, o da sua falta de contato com a cultura, o da sua inexperiência literária" (LINS, 1963, p.242-246).

\section{A noção de representação em oposição à crítica marxista}

A despeito de empreender uma crítica sem maior aprofundamento analítico e mais preocupada em apontar apenas os defeitos de Jorge Amado, o que Álvaro Lins e os detratores da literatura amadiana fizeram foi tomar a biografia do autor e seu contexto sócio-histórico como as únicas possibilidades de interpretação para o texto literário. Assim, construíram uma análise da obra baseada em uma concepção marxista do determinismo socioeconômico, a partir de uma perspectiva materialista, considerando a literatura como mero reflexo da realidade ou da psicologia do autor. Em oposição a esses modelos reducionistas e deterministas, o que propomos é, justamente, compreender o texto amadiano por meio do conceito de "representação", na esteira dos estudos de Louis Marin e Roger Chartier, o considerando como a representação das sensibilidades de determinados homens em momentos específicos da história, da ideia que faziam de sua própria sociedade, dos significados que pretendiam construir, como uma elaboração multifacetada e que envolve um conjunto de práticas impregnadas de posições e escolhas. Assim, o discurso da ficção é mimético, mas imita outros discursos correntes daquela sociedade, não exatamente a realidade empírica, porque a 


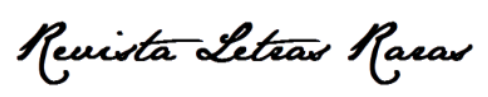

ISSN: 2317-2347 - v. 9 , n. 2 (2020)

Todo o conteúdo da RLR está licenciado sob Creative Commons Atribuição 4.0 Internacional

verossimilhança desses textos se dá a partir do conjunto dos regimes de verdade que uma determinada sociedade legitima.

Posto isso, o que defendemos é uma oposição à ideia de que a obra, circunscrita pela crítica marxista como romance proletário e regionalista, seja uma homologia das estruturas sociais da realidade que lhe é referente, uma vez que buscamos construir uma análise mais próxima das correntes teóricas que investigam a cultura não como um nível de realidade adstrito às determinações socioeconômicas, mas como uma dimensão complexa do homem que, de maneira alguma, pode ser explicada apenas por modelos assentados no materialismo histórico. Nesse sentido, a ideia de uma conservação do passado na obra literária que defendemos se distancia da concepção de espelhamento ou de transposição da realidade social para a ficção, uma vez que pretendemos analisar o romance Cacau não enquanto documento histórico, ou como reflexo de uma conjuntura social e econômica que nos permita reconstruir a sociedade grapiúna dos fins do século XIX e início do século XX tal qual ela existiu. Nosso objetivo é, precisamente, escapar dessa leitura muito comum na tradição da crítica literária, fundamentada na noção de que a obra é uma construção ideológica determinada pelo lugar social do autor e que o texto só pode ser interpretado por um referente exterior a ele próprio.

Destarte, a proposta dos historiadores ligados à Nova História Cultural, a partir da década de 1980, nos parece a mais razoável para ler o texto amadiano, porque objetiva decifrar as sociedades de outra maneira: compreendendo as modalidades do agir e do pensar, por meio das noções de "práticas" e "representações", que podem ser úteis para examinar os objetos culturais produzidos, os sujeitos produtores e receptores, os processos que constituem essa produção e as normas a que se conformam as sociedades através da consolidação de seus costumes. O campo das "práticas" e "representações", que abarca noções como "apropriação" e "negociação", nos parece, nesse sentido, a melhor alternativa para investigar o texto literário amadiano em uma perspectiva da literatura como algo construído a partir de uma "estrutura de pensamento" que atuou em determinado período, em um determinado espaço físico:

As representações do mundo social assim construídas, embora aspiram à universalidade de um diagnóstico fundado na razão, são sempre determinadas pelos interesses de grupo que as forjam. Daí, para cada caso, o necessário relacionamento dos discursos proferidos com a posição de quem os utiliza (CHARTIER, 1998, p.17). 


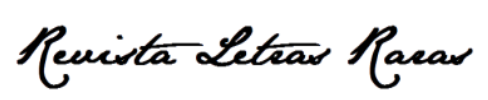

ISSN: 2317-2347 - v. 9 , n. 2 (2020)

Todo o conteúdo da RLR está licenciado sob Creative Commons Atribuição 4.0 Internacional

Em Cacau, somos conduzidos por um narrador-personagem que, logo no primeiro capítulo, intitulado "Fazenda Fraternidade", nos apresenta o cenário do enredo e as péssimas condições vividas pelos trabalhadores rurais na propriedade do coronel Manuel Misael de Sousa Teles, o "rei do cacau", ou Mané Frajelo, apelido pejorativo dado pelos próprios empregados. Depois de apresentar alguns personagens que irão compor a trama, como Colodino, Antônio Barriguinha e Honório, todos contratados na fazenda, o narrador faz um corte temporal para, no capítulo seguinte, voltar à própria infância no Estado de Sergipe. Filho do dono de uma fábrica de tecidos na cidade de São Cristóvão, o menino, apesar de pertencer a uma classe mais abastada da região, desde cedo teve contato com os empregados da confecção e os moradores dos bairros pobres. Com a morte do pai, ainda na infância, passou a trabalhar na empresa da família, que agora era administrada pelo tio, um homem sem escrúpulos que conseguiu aumentar os lucros da fábrica e ampliar os negócios à custa da exploração dos funcionários.

$\mathrm{Na}$ adolescência, depois de uma desavença com o tio, que o levou à demissão da fábrica, o jovem ouviu as promessas de riqueza e prosperidade das lavouras de cacau em Ilhéus, no sul da Bahia, e decidiu aventurar-se junto a uma massa de sergipanos atraídos pela terra dos frutos de ouro. É assim que a narrativa, aos poucos, nos leva de volta ao ponto de início, a Fazenda Fraternidade, e ficamos sabendo que o narrador-personagem foi um dos empregados do coronel Misael, um dos chamados "alugados", homens que são contratados em condições análogas à escravidão, que moram em barracos improvisados e que são obrigados a comprar comida e demais mantimentos em estabelecimentos de propriedade do próprio contratante. Através do Sergipano, como é chamado pelos companheiros, conhecemos a rotina na plantação, colheita e beneficiamento do cacau, os "heróis da tocaia" e jagunços que fazem a segurança dos coronéis e ajudam a manter, por meio da repressão violenta, a ordem e o bom funcionamento da fazenda, bem como os pouquíssimos momentos de diversão dos trabalhadores, aos finais de semana, nas casas de prostituição de vilarejos pobres da região. Para os espoliados, vítimas do coronelismo, a pobreza, o trabalho forçado e a condições subhumanas eram encaradas como naturais:

Ninguém reclamava. Tudo estava certo. A gente vivia quase fora do mundo e a nossa miséria não interessava a ninguém. A gente ia vivendo por viver. Só muito de longe surgia a ideia de que um dia aquilo podia mudar. Como, não sabíamos. Nós todos não poderíamos chegar a fazendeiro. Em mil, um enriquecia (AMADO, 1971, p.151). 


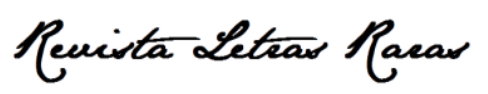

ISSN: 2317-2347 - v. 9 , n. 2 (2020)

Todo o conteúdo da RLR está licenciado sob Creative Commons Atribuição 4.0 Internacional

Aos poucos, à medida que é afetado pela dura realidade dos trabalhadores campesinos nas fazendas de cacau, Sergipano vai adquirindo uma "consciência de classe", ainda que não consiga elaborar exatamente o que isso signifique. A rotina da Fazenda Fraternidade é interrompida pela chegada do coronel Misael e sua família para os tradicionais festejos do São João. É quando Sergipano conhece a bela Mária, filha do "rei do cacau", que acaba afeiçoandose por ele. Mária pede ao pai que coloque o trabalhador à sua disposição para os dias em que estiver na fazenda e, assim, Sergipano se aproxima da filha do patrão, que não demora a se apaixonar por ele e the propõe casamento. $O$ trabalhador, no entanto, rejeita o pedido da moça, porque Mária coloca como condição para o matrimônio que ele deixe de ser empregado e passe a ser patrão, mas Sergipano não aceita e prefere se manter firme ao lado dos trabalhadores, dos mais pobres: "O amor pela minha classe, pelos trabalhadores e operários, amor humano e grande, mataria o amor mesquinho pela filha do patrão. Eu pensava assim e com razão" (AMADO, 1971, p.221).

Em um dos últimos capítulos do romance, denominado de "Correspondência", o narrador-personagem, chamado durante toda a narrativa de Sergipano, revela que se chama José Cordeiro e teve a ideia de escrever a história depois de ler as cartas de trabalhadores rurais, prostitutas e amigos que guardou após o período na Fazenda Fraternidade: "Depois, já no Rio de Janeiro, relendo essas cartas, pensei em escrever um livro. Assim nasceu 'Cacau'. Não é um livro bonito, de fraseado, sem repetição de palavras. É verdade que eu hoje sou operário, tipógrafo, leio muito, aprendi muita coisa" (AMADO, 1971, p.210). Ao revelar o narrador do texto e atribuir sua autoria a um homem que não tinha o pleno domínio dos recursos estilísticos da literatura, ainda que tenha se tornado um tipógrafo, mas que conhecia a realidade dos trabalhadores rurais e dos operários nas fábricas, o autor demonstra estar de acordo com aquilo que preconizou na nota de abertura do romance: "mínimo de literatura para um máximo de honestidade". Assim, se o texto carece de construções mais elaboradas e se há uma ou outra falha do ponto de vista estético, é porque a realidade precisa ser apresentada de forma crua e direta, por quem a experimentou.

Nesse sentido, como já mencionamos inicialmente, podemos dizer que Jorge Amado está em conformidade com aquilo que os seus coetâneos, a chamada geração do romance de 30, buscava na literatura brasileira: a produção de narrativas que retratassem aqueles historicamente esquecidos por meio de uma linguagem que os representasse. No entanto, ainda que Jorge Amado tenha um objetivo específico nessa direção e construa sua narrativa a partir do 


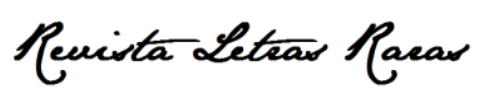

ISSN: 2317-2347 - v. 9 , n. 2 (2020)

Todo o conteúdo da RLR está licenciado sob Creative Commons Atribuição 4.0 Internacional

realismo social, esta não é a única maneira de ler o romance amadiano. Conforme Jauss, sabemos que a vida histórica de uma obra literária é inconcebível sem a participação ativa de seu destinatário e que a experiência estética, portanto, não tem início pela compreensão e interpretação do significado oculto de uma obra, muito menos pela reconstrução das intencionalidades do autor que a criou. Os estudos de recepção, por outro lado, nos mostram que a significação do texto não é "expressão de algo outro", anterior e independente dele, por isso mesmo refuta a ingenuidade da asserção de que a literatura é a expressão da realidade. Sendo assim, o mundo real não é dado ao texto antecipadamente, mas ele o obtém através de uma relação que se estabelece entre a obra e o leitor, este último impregnado de orientações e valores que ele próprio não tem consciência. Para usar as palavras de Lima, lendo Jauss: "é o efeito (produto de orientações e valores) atualizado no leitor que lhe serve de filtro para emprestar sentido à indeterminação contida na estrutura do texto" (LIMA, 1970, p.24). Por "indeterminação", presente na estrutura do texto, podemos compreender aquilo que se apresenta como lacuna a ser preenchida pelo leitor, como uma brecha que causa hesitação ou ambiguidade, e que distingue o texto literário, por exemplo, de uma mensagem pragmática ou um teorema.

Assim, da mesma maneira que o conceito de "representação", analisado a partir dos estudos de Chartier, nos permite escapar da ideia de que toda obra literária é produto de um determinado momento histórico, de uma "totalidade homogênea, dotada de uma significação ideal e única presente em cada uma das manifestações que a exprime" (CHARTIER, 2002), o pensamento de Jauss, ao afirmar que o significado é engendrado no processo de leitura, nos ajuda a evitar também tanto a visão marxista da contemplação histórica quanto a formalista da contemplação meramente estética. Ambos os métodos enxergam o objeto literário encerrado no círculo dos sistemas de produção, no caso do materialismo histórico, e de pura representação estética, no caso do formalismo.

À vista disso, se pensarmos em um sistema de poder privado com enorme influência política e econômica, que se estabelece no Brasil no final do século XIX e início do XX, durante a República Velha, mas com raízes fincadas no período colonial, podemos utilizar o conceito de representação para analisar de que maneira as práticas e os signos do coronelismo serviram para classificação e hierarquização social e, mais ainda, como formas institucionalizadas pelas quais determinados representantes encarnaram a coerência de uma comunidade, uma identidade social própria e, assim, legitimaram seu domínio. Examinar esse sistema de 


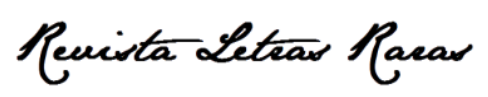

ISSN: 2317-2347 - v. 9 , n. 2 (2020)

Todo o conteúdo da RLR está licenciado sob Creative Commons Atribuição 4.0 Internacional

dominação a partir da representação empreendida por Amado em Cacau, nos permite compreender as relações que o próprio autor mantinha com essa prática. Ao reconstituir a llhéus dos fins do XIX e início do XX, Amado o faz, de acordo com depoimentos do próprio escritor, a partir de suas lembranças pessoais e familiares, de conversas com idosos, de histórias ouvidas durante a infância nas fazendas de Ferradas, onde nasceu. Ou seja, o narrador, como dizia Benjamin, vai buscar na experiência pessoal a matéria-prima para suas narrativas, sendo as melhores aquelas que menos se distinguem das histórias orais contadas pelos inúmeros narradores anônimos. Assim, a mentalidade deste indivíduo, seja ele um narrador ou não, é justamente o que ele tem de comum com outros homens do seu tempo. Para Chartier, o nível da história das mentalidades é o do cotidiano e do automático, é aquilo que escapa aos sujeitos individuais da história porque revelador do conteúdo impessoal do seu pensamento (CHARTIER, 1998, p.41).

[...] qualquer fonte documental que for mobilizada para qualquer tipo de história nunca terá uma relação imediata e transparente com as práticas que as designa. Sempre a representação das práticas tem razões, códigos, finalidades e destinatários particulares. Identificá-los é uma condição obrigatória para entender as situações ou práticas que são o objeto da representação (CHARTIER, 2011, p.16).

Ao expor o mandonismo e os mecanismos do regime político-econômico coronelista, fundamentado na opressão e na violência, revelando tensões sociais próprias daquele período e ancorado em personagens que parecem indicar a representação de figuras históricas da região, o discurso literário amadiano estabelece uma relação de "negociação" com a realidade social. Por isso, não podemos dizer que o coronel Manuel Misael de Souza Teles, personagem amadiano, seja o mesmo Manuel Misael da Silva Tavares, um dos maiores produtores de cacau da região sul da Bahia, também conhecido como "rei do cacau", e considerado pelos historiadores como o mais promissor cacauicultor do país: "Misael Tavares possuía cerca de dezoito fazendas, empregando nos trabalhos diários mais de quatrocentos homens e era um dos poucos fazendeiros locais a colher mais de quarenta mil arroubas de cacau" (FALCÓN, 2010, p.60). Na ficção de Amado, o narrador se refere a ele como "ricaço", "senhor feudal" e "rei do cacau" (AMADO, 1971, p.179).

Para Chartier, algumas obras literárias têm a capacidade de moldar as representações coletivas do passado de uma maneira muito mais poderosa que os escritos dos historiadores, 


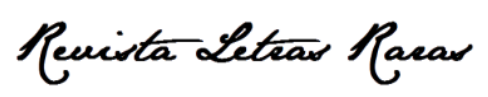

ISSN: 2317-2347 - v. 9 , n. 2 (2020)

Todo o conteúdo da RLR está licenciado sob Creative Commons Atribuição 4.0 Internacional

porque há nelas uma força, chamada de "energia social", apta a apropriar-se de instâncias do real, mas que não são o real (CHARTIER, 2009, p.25). O referente, nesse sentido, pode até desencadear o processo, mas ele não o conduz, nem o completa, porque o significado é construído sempre fora do referente. Ainda que, de certa maneira, contígua à realidade, entendemos que a ficção é um mundo à parte. Podemos dizer que as fronteiras que separam um e outro são porosas e facilmente transponíveis, no entanto, aqui, entendemos a fronteira não no sentido de demarcação e delimitação, mas enquanto lugar de trânsito, de comunicação e diálogo:

A literatura registra e expressa aspectos múltiplos do complexo, diversificado e conflituoso campo social no qual se insere e sobre o qual se refere. Ela é constituída a partir do mundo social e cultural e, também, constituinte deste; é testemunha efetuada pelo filtro de um olhar, de uma percepção e leitura da realidade, sendo inscrição, instrumento e proposição de caminhos, de projetos, de valores, de regras, de atitudes, de formas de sentir... Enquanto tal é registro e leitura, interpretação, do que existe e proposição do que pode existir, e aponta a historicidade das experiências de invenção e construção de uma sociedade com todo seu aparato mental e simbólico (BORGES, 2010, p.98).

A ideia de representação propõe a identificação e o entendimento de forças reguladoras que agem sobre a vida coletiva dos indivíduos, construídas a partir do real, cuja importância não é estabelecida pelo critério de verdade, mas pelo de credibilidade. Desse modo, as representações não são um reflexo da realidade, mas uma elaboração do real a partir de um conjunto variado de aspectos sociais, culturais, políticos e institucionais. Nessa perspectiva, representar é dar sentido ao ausente, é também criar, porque, muitas vezes, aquele que representa descreve uma sociedade como imagina que ela seja, ou como desejaria que ela fosse. Conforme Marin:

Esse seria o primeiro efeito da representação em geral: fazer como se outro, 0 ausente, estivesse presente; mas não uma efetiva presença, e sim um efeito de presença. Não se trata do mesmo, mas ocorre como se fosse 0 mesmo e, às vezes, até mais que o mesmo (MARIN, 2009, p.137)

No ensaio Poderes e limites da representação: Marin, o discurso e a imagem (2002), Chartier destaca o caráter de duplicidade do conceito. De um lado, representar é, como dissemos, conferir presença a uma ausência, por outro, é também exibir uma presença enquanto imagem. Chartier refere que Marin recorre a uma acepção do termo de um clássico dicionário 


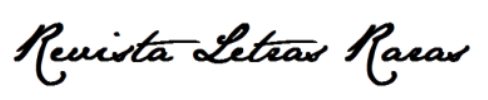

ISSN: 2317-2347 - v. 9 , n. 2 (2020)

Todo o conteúdo da RLR está licenciado sob Creative Commons Atribuição 4.0 Internacional

francês de 1727 (Furetière) para encontrar estes dois sentidos, aparentemente opostos, para 0 vocábulo representação.

No primeiro sentido, representar é quando uma imagem toma o lugar de um "objeto ausente (coisa, conceito ou pessoa)", sendo capaz de substituí-lo apropriadamente. "Representar é, pois, fazer conhecer as coisas mediatamente "pela pintura de um objeto", "pelas palavras e pelos gestos", "por algumas figuras, por algumas marcas" - como os enigmas, os emblemas, as fábulas, as alegorias" (CHARTIER, 2002, p.165). Em um discurso mais utilizado na política e no meio jurídico, podemos dizer de uma pessoa que se coloca no lugar de outra e, por meio dessa substituição, assume o poder e a autoridade da primeira. Já na segunda acepção do termo, referida no Furetière, representar é também a "demonstração de uma presença, a apresentação pública de uma coisa ou de uma pessoa" (CHARTIER, 2002, p.166). Assim, a imagem e o referente são a mesma coisa.

\begin{abstract}
Assim, através da representação do passaporte na fronteira, o titular não apenas aparece nele, mas também apresenta sua presença legítima pelo sinal que 0 autoriza ou permite, e até 0 obriga. A representação permanece aqui no elemento da mesma e a intensifica dobrando-a. Nesse sentido, é seu reflexo, e representar sempre será apresentar-se como representante de algo. Ao mesmo tempo, a representação constitui seu sujeito. Esse seria o segundo efeito da representação em geral, o de constituir um sujeito pela reflexão do dispositivo representativo (MARIN, 2009, p.137, tradução nossa).
\end{abstract}

O discurso literário de Amado evoca a figura emblemática do "coronel" que, ao entrar em cena, se "apresenta representando algo" em uma dimensão reflexiva da representação. Como 0 fazendeiro Manuel Misael de Cacau, os coronéis do cacau, na maior parte das vezes, não precisavam utilizar a força física ou a violência para impor seu domínio, porque recorriam, quase sempre, às formas da dominação simbólica. Seja pela própria imagem, pela exibição, ou mesmo pelo aparato, o poder do "coronel" estava representado por dispositivos à volta dele: a presença constante de jagunços, as botinas, esporas, o chapéu, os rebenques, o parabélum. Artifícios que representavam a potência do "coronel" e suscitavam, sem recorrer a qualquer ato de violência, a submissão e a obediência incondicional. Nesse sentido, os instrumentos da dominação simbólica asseguram ao mesmo tempo "a negação e a conservação do absoluto da força", como adverte Marin: "negación, porque la fuerza no se ejerce ni se manifiesta y porque está en paz en los signos que la significan y la designan; conservación, porque la fuerza, por y en la representación, 


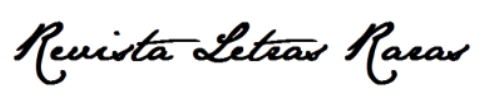

ISSN: 2317-2347 - v. 9 , n. 2 (2020)

Todo o conteúdo da RLR está licenciado sob Creative Commons Atribuição 4.0 Internacional

se dará como justicia, es decir como ley obligatoriamente vinculante bajo pena de muerte" (MARIN, 2009, p.137).

Em certa medida, o exercício da dominação política na sociedade grapiúna, pelos coronéis do cacau, teve respaldo na "exibição" continuada de um aparato de formas simbólicas, que contribuíram, consideravelmente, para a relativa conformação social no seio dessa estrutura opressora e desigual que era o sistema coronelista. A dominação simbólica, portanto, garantia que trabalhadores rurais, negros e mestiços, sob regime análogo à escravidão, aceitassem as condições impostas pelos coronéis, a ponto de incorporar essa exploração e, assim, naturalizálas.

No entanto, sabemos que esse sistema de dominação simbólica que operava no coronelismo não se restringia apenas à violência física e sua natureza repressiva, enquanto negação e a conservação do absoluto da força. No discurso literário de Amado no referido romance, assim como em outros textos do chamado "ciclo do cacau", encontramos algumas pistas das relações de sociabilidade existentes entre os coronéis e seus empregados. No capítulo "Jaca", por exemplo, o autor descreve o batismo de crianças, filhos dos trabalhadores rurais, pelo coronel Manuel Misael. Assim, à figura do grande cacauicultor, dono da terra, do seu povo, e das suas leis, também se associava a imagem de um protetor, defensor dos seus "homens", de suas "posses". O costume de "apadrinhar" os filhos e sobrinhos de empregados dão ao coronel outras formas de reconhecimento e respeito, que não apenas a via repressiva. $A$ prática, comum também nas relações entre senhor e escravo durante o regime escravocrata, não deixa de ser uma legitimação do paternalismo, que diz respeito a "uma outra forma de controle mais eficaz do que o chicote do feitor", "em que o dominado aceita o sistema desde que sejam respeitados certos direitos e privilégios, e também que seja possível a barganha" (REIS, 1989, p.102).

Os batizados realizavam-se de ano em ano, pelo Natal. O coronel e a família convidavam um padre para celebrar uma missa na roça. Famílias de llhéus, Itabuna e Pirangi enchiam a casa-grande. Sacrificavam-se porcos, galinhas, perus e carneiros, e eles dançavam à noite, ao som de uma vitrola. Oito dias de farra daquele pessoal da cidade, que evitava tocar na gente com medo de se sujar e que puxava, de longe, conversa para gozar as besteiras que a gente dizia. Com o dia de Natal chegava a grande festa. Trabalhadores dos mais distantes pontos, famílias inteiras de contratistas, vinham a pé batizar os filhos (AMADO, 1971, p.75). 


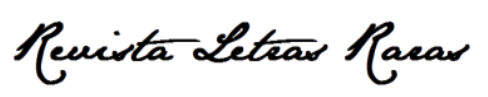

ISSN: 2317-2347 - v. 9 , n. 2 (2020)

Todo o conteúdo da RLR está licenciado sob Creative Commons Atribuição 4.0 Internacional

Se por um lado, há um mecanismo que opera por meio da violência física e simbólica, por outro lado, precisamos considerar que o apadrinhamento, sobretudo no século XIX, era visto como uma estratégia buscada pelos empregados das fazendas, negros e mestiços, para alcançar uma maior inserção nesta sociedade. Através do apadrinhamento, por exemplo, muitos deles tinham acesso a um conjunto de práticas e saberes que, de outra maneira, Ihes seria impossível alcançar. Em Cacau, até o modo de tratar o coronel e seus familiares mudava depois que os filhos dos trabalhadores eram batizados: "Passavam a chamar o coronel de padrinho e Mária de madrinha" (AMADO, 1971, p.177). Essa prática contraditória demonstra que havia um espaço de barganha entre opressor e oprimido, o que desmistifica a ideia de um poder hegemônico e absoluto.

[...] É óbvio que os senhores e seus agentes detinham uma enorme vantagem inicial, baseada no acesso e poderosos recursos materiais, sociais, militares e simbólicos. Por isso os escravos tiveram de enfrentá-los com inteligência e criatividade. Eles desenvolveram uma fina malícia pessoal, uma desconcertante ousadia cultural, uma visão de mundo aberta ao novo (REIS, 1989, p.33).

Reis nos adverte para a existência de táticas de resistência que desencadearam algumas rupturas no sistema de dominação através de pequenos atos de desobediência e manipulação. Como refere Michel de Certeau, a despeito da visão de que os dispositivos operados pelas forças de dominação pretendem sempre produzir controle e coerção, o "homem comum" também tem a capacidade de engendrar artifícios de resistência para fazer frente a esses mecanismos que intentam controlá-lo. Certeau chama estes mecanismos de "táticas" e, assim, as define:

[...] Um cálculo que não pode contar com um próprio, nem portanto com uma fronteira que distingue o outro como totalidade visível. A tática só tem por lugar 0 do outro. Ela aí se insinua, fragmentariamente, sem apreendê-lo por inteiro, sem poder retê-lo à distância. Ela não dispõe de base onde capitalizar seus proveitos, preparar suas expansões e assegurar uma independência em face das circunstâncias. [...] Ao contrário, pelo fato de seu não lugar, a tática depende do tempo, vigiando para 'captar no voo' possibilidades de ganho. 0 que ela ganha, não guarda. Tem constantemente que jogar com os acontecimentos para os transformar em 'ocasiões'. Sem cessar, o fraco deve tirar partido de forças que lhe são estranhas. Ele o consegue em momentos oportunos onde combina elementos heterogêneos [...], mas a sua síntese intelectual tem por forma não um discurso, mas a própria decisão, ato e maneira de aproveitar a 'ocasião' (CERTEAU, 1998, p. 46-47). 


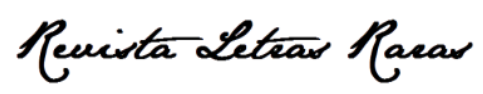

ISSN: 2317-2347 - v. 9 , n. 2 (2020)

Todo o conteúdo da RLR está licenciado sob Creative Commons Atribuição 4.0 Internacional

Em Cacau, essas táticas não chegam a promover uma transformação efetiva nas personagens que as engendram, como acontece por exemplo com Negra Risoleta, ex-escrava e trabalhadora numa fazenda de cacau em Terras do Sem Fim (1943), que se beneficia do batismo do coronel para obter privilégios e até auferir terras para plantação. Porém, tanto no primeiro quanto no segundo romance há uma desigualdade profunda e um absoluto impedimento de mobilidade social destas personagens. Ainda que as duas obras sejam classificadas pela crítica brasileira como "romance proletário" ou "romance social", uma vez que atribui-se a elas uma orientação leninista-marxista, tendo como referencia o modelo do realismo soviético, não podemos dizer exatamente que os textos incitam as classes operárias à revolução. Talvez o contrário, porque qualquer tentativa de revolta e mobilização dos campesinos em Cacau é completamente rechaçada e boicotada antes que tenha início. Em alguns momentos do romance, o Sergipano até demonstra ter consciência da violência a que estão submetidos: "Pobres mulheres, que choravam, rezavam e se embriagavam na Rua da Lama. Pobres operárias do sexo. Quando chegará o dia de vossa libertação" (AMADO, 1971, p.164). Em outro trecho, após uma conversa com Colodino, carpinteiro que morava no mesmo barraco que José Cordeiro na fazenda, o narrador-personagem reflete sobre a condição nas fazendas de cacau: "Olhávamos os cacaueiros e não achávamos a solução. Se nós não estivéssemos muito acostumados com a miséria, os suicídios seriam diários. Não haveria um meio de sair daquela situação?" (AMADO, 1971, p.184).

Os proletários, assim, não encontram saída para a exploração a que estão submetidos, eles não se rebelam, tampouco se posicionam contra a estrutura coronelista. Aqueles que não concordam com a condição de semi-escravidão nas fazendas de cacau preferem ir embora, tentar a vida em outras terras, deixando para trás os companheiros que continuarão a ser espoliados. José Cordeiro, o personagem-narrador, chega a planejar uma revolta quando 0 coronel Manuel Misael diminui, sem explicações, o salário de todos os trabalhadores da roça. 0 motim, no entanto, não ganha força, porque eles imaginam que o patrão irá demiti-los para contratar outras pessoas que trabalhariam pelo valor estabelecido:

- Estamos vencidos antes de começar a luta.

- Nós já nasce vencido... - sentenciou Valentim.

Baixamos as cabeças. E no outro dia voltamos ao trabalho com quinhentos réis de menos (AMADO, 1971, p.216). 


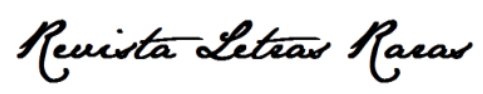

ISSN: 2317-2347 - v. 9, n. 2 (2020)

Todo o conteúdo da RLR está licenciado sob Creative Commons Atribuição 4.0 Internacional

\section{Conclusões}

Em suma, o que encontramos na narrativa amadiana é a total impossibilidade de ascensão das classes desfavorecidas e a consolidação do poder dos coronéis. Portanto, não há indignação, não há revoltas, não há greves. Se fôssemos construir uma crítica a partir do materialismo histórico, que valoriza os dados biográficos do autor, poderíamos dizer que o que 0 romance faz, ao invés de denúncia social, é uma reafirmação dos valores intocáveis da sociedade coronelista ilheense e empreende uma verdadeira apologia às classes dominantes e à burguesia agrária grapiúna, da qual, inclusive, o próprio Jorge Amado fez parte. Como sabemos, o escritor é filho de um coronel de cacau, o fazendeiro João Amado. No entanto, a proposta não é seguir nessa direção, uma vez que refutamos esses modelos reducionistas que pretendem interpretar o texto a partir de determinismos. $O$ que isso parece demonstrar é o caráter complexo e heterogêneo do próprio texto amadiano.

Desse modo, acreditamos que o conceito de representação pode abranger essa dimensão da literatura de Jorge Amado, permitindo a compreensão das relações que o autor ou o grupo do qual ele faz parte mantêm com o mundo social de uma maneira muito mais eficaz do que a noção de mentalidade, uma vez que esta pode sugerir a ideia de uma suposta objetividade das estruturas sociais, em oposição à subjetividade da concepção de representação como uma construção multifacetada, que envolve um conjunto de práticas variadas, constituídas de posições, escolhas e interesses. Como já referimos, a noção dá conta de entender o conjunto das formas "teatralizadas e estilizadas" pelas quais os homens e as sociedades constroem imagens de si mesmos, que "não são uma expressão imediata, automática, objetiva, do estatuto de um ou do poder do outro. Sua eficácia depende da percepção e do julgamento de seus destinatários, da adesão ou da instância ante mecanismos de apresentação e de persuasão postos em ação" (CHARTIER, 2002, p. 177-178).

\section{Referências}

AGUIAR, Joselia. Jorge Amado: uma biografia. São Paulo: Todavia, 2018.

AMADO, Jorge. Cacau. São Paulo: Editora Martins, 1971. Terras do Sem Fim. São Paulo: Editora Martins, 1971. 


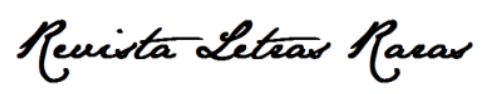

ISSN: 2317-2347 - v. 9 , n. 2 (2020)

Todo o conteúdo da RLR está licenciado sob Creative Commons Atribuição 4.0 Internacional

BORDIEU, Pierre. O Poder Simbólico. Trad. Fernando Tomaz. Rio de Janeiro: Editora Bertrand Brasil, 2009.

BORGES, Valdeci Rezende. História e Literatura: Algumas considerações. Revista de Teoria da História, Universidade Federal de Goiás, Ano 1, Número 3, p.94-109, junho/2010.

CANDIDO, Antonio. Literatura e Sociedade. Rio de Janeiro: Ouro sobre Azul, 2006.

. A educação pela noite. Rio de Janeiro: Ouro sobre azul, 2011.

Poesia, documento e história. Jorge Amado: Povo e terra. 40 anos de literatura. São Paulo, Martins, 1972.

CERTEAU, Michel de. A invenção do cotidiano. Trad. Epraim Ferreira Alves. Petrópolis: Editora Vozes, 1998.

CHARTIER, Roger. A História Cultural: entre práticas e representações. Trad. Maria Manuela Galhardo. Lisboa: Difusão Editorial, 1998.

À beira da falésia: a história entre incertezas e inquietude. Trad. Patrícia Chittoni Ramos Porto Alegre: Ed. Universidade UFRGS, 2002.

p.15-29, jul/dez 2011.

Defesa e ilustração da noção de representação. Fronteiras, Dourados, MS, v.13, n.24,

A história ou a leitura do tempo. Trad. Cristina Antunes. Belo Horizonte: Autêntica, 2009.

DUARTE, Eduardo de Assis. Jorge Amado: romance em tempo de utopia. Rio de

Janeiro; São Paulo: Record, 1996.

FALCÓN, Gustavo. Coronéis do cacau. Salvador, BA: Solisluna Design Editora, 2010.

HOLANDA, Sérgio Buarque de. Três romances. Suplemento Arte Literatura. Belém. n.

104, 1948.

JAUSS, Hans Roberto. A história da literatura como provocação à teoria literária. Trad. Sérgio Tellaroli. São Paulo: Editora Ática, 1994.

LIMA, Luiz Costa (Introd. e seleção). A literatura e o leitor. Textos de estética da recepção. Rio de Janeiro: Paz e Terra, 1979.

LINS, Álvaro. Os Mortos de Sobrecasaca. Ensaios e estudos: 1940-1960. Rio de Janeiro: Civilização Brasileira, 1963.

MARIN, Louis. Poder, representación, imagen. Prismas - Revista de Historia Intelectual, vol. 13, núm. 2, julio-diciembre, 2009, pp. 135-153.

Le Portrait du roi. Paris: Éditions de Minuit, 1981.

MARTINS, José de Barros. Jorge Amado: Povo e terra. 40 anos de literatura. São Paulo, Martins, 1972.

MARTINS, Wilson. Crise no romance brasileiro. Suplemento Arte Literatura. Belém. n. 38, p.1, 1947.

REIS, João José. Negociação e conflito: a resistência negra no Brasil escravista / Eduardo Silva, João José Reis. São Paulo: Companhia das Letras, 1989. 